\title{
Hydrogeochemical and isotopic studies of groundwater in the middle voltaian aquifers of the Gushegu district of the Northern region
}

\author{
Musah Salifu $^{1}$ - Sandow Mark Yidana ${ }^{2}$ Maxwell Anim-Gyampo ${ }^{3}$. \\ Michael Appenteng ${ }^{1} \cdot$ David Saka $^{1} \cdot$ Felix Aidoo $^{1} \cdot$ Enoch Gampson $^{1}$. \\ Mark Sarfo
}

Received: 8 May 2013/Accepted: 1 October 2015/Published online: 18 October 2015

(C) The Author(s) 2015. This article is published with open access at Springerlink.com

\begin{abstract}
This work is to establish the hydrochemistry and origin of groundwater in some parts of the Gushegu district of the Northern Region of Ghana. Hydrochemical data from 19 groundwater and 7 rock samples have been used to evaluate water quality, water types, and sources of various ions as well as origin of the groundwater. The study results show that the quality of groundwater from the area is generally not good due to their fluoride $\left(\mathrm{F}^{-}\right)$, bicarbonate $\left(\mathrm{HCO}_{3}{ }^{-}\right)$and electrical conductivity (EC) concentrations. The $\mathrm{F}^{-}$contents of the groundwater have values as high as $1.97 \mathrm{mg} / \mathrm{L}$, with $53 \%$ of the groundwater having concentrations of $\mathrm{F}^{-}$exceeding the WHO recommended allowable limits. These high $\mathrm{F}^{-}$values have the potential of causing serious health problems such as kidney failure, dental and skeletal fluorosis, reproductive problem and reduction in intelligent quotient of consumers. A plot of Gibbs diagram reveals that rock weathering and precipitation are the major hydrogeochemical processes regulating the water chemistry of the study area. Petrographic thinsection analyses of rock samples identify minerals present to be muscovite, plagioclase feldspars, quartz, sericite and iron oxide. Stable isotope $\left({ }^{18} \mathrm{O}\right.$ and $\left.{ }^{2} \mathrm{H}\right)$ composition of the waters reveals that most of the groundwater is likely to be recharged from local precipitation, indicating their
\end{abstract}

Musah Salifu

geomoba2003@yahoo.com

1 National Nuclear Research Institute, Ghana Atomic Energy Commission, P.O.Box LG 80, Legon, Accra, Ghana

2 Department of Earth Science, University of Ghana, Accra, Ghana

3 Department of Earth and Environmental Science, University for Development Studies, P.O.Box 24, Navrongo, Ghana meteoric origin. Some samples, however, showed considerable evaporation.

Keywords Gushegu - Fluoride - Voltaian aquifers · Muscovite $\cdot$ Sericite $\cdot$ Stable isotopes

\section{Introduction}

The Northern region of Ghana consists of 18 administrative districts with Tamale as its regional capital. Access to enough pipe-borne water in the other districts in the region including the Gushegu district except Tamale is very limited. The Northern region is amongst the poorest and economically deprived regions of Ghana. The Gushegu district is predominantly rural and this has resulted in more than its 300 communities to dwell mainly on rivers, streams, jets, rain waters, dams, hand-dug wells and boreholes. However, increased contamination and pollution of surface waters through natural and anthropogenic activities have prompted the residents to shift their attention mainly to the use of groundwater for their domestic activities. Although groundwater is generally buffered from most surface polluting activities (Yidana and Yidana 2010), its quality can deteriorate with time as a result of increasing pollution of surface waters. (Appelo and Postma 1993) defined water quality as its suitability for human consumption, domestic use and irrigation. The groundwater system in any area varies in chemistry mainly due to chemical alteration of meteoric water recharging the aquifer system (Back 1966; Drever 1988; Hem 1991). According to Gibbs (1970), the possible factors that control water chemistry are weathering of rocks, atmospheric precipitation, evaporation and crystallization. The chemical quality of groundwater depends on the characteristics of 
the soil and rock media through which it passes en route the groundwater zone of saturation (Raji and Alagbe 1997; Acheampong and Hess 1998; Olayinka 1999; Foster et al. 2000). UNESCAP (2000) revealed that 15 out of every 1000 children born in the developing world die before the age of five from diarrhea caused by drinking polluted water. For example, (Apambire et al. 1997) revealed the presence of fluoride as high as $4.6 \mathrm{mg} / \mathrm{L}$ in groundwater in the Bongo granites of the Upper East Region of Ghana. This has resulted in the prevalence of dental fluorosis and quiet recently the emergence of skeletal fluorosis in the area. Other negative effects of high fluoride in groundwater include reduction of intelligent quotient and kidney damage.

The Gushegu district is underlain by rocks of the Voltaian Supergroup (Bertrand-Sarfati et al. 1990). The Voltaian Basin is the least in terms of groundwater potential as far as groundwater potential of Ghana is concerned (Dapaah-Siakwan and Gyau-Boakye 2000). Various studies have been carried out in Ghana concerning the characterization of the hydrochemistry of the Voltaian aquifers (Yidana and Yidana 2010). Works by Acheampong and Hess (1998), Yidana et al. (2008) suggest groundwaters of the Southern Voltaian and Afram plains are controlled by weathering of albitic feldspars and silicate minerals, respectively. For example, Yidana et al. (2008) used the mass balance and multivariate techniques to define silicate mineral weathering as the primary control on the hydrochemistry of groundwater from the Afram Plains area. However, these works have been limited to the Southern part of the Voltaian. The Voltaian system is one of the two major hydrogeological formations in Ghana and underlies about $45 \%$ of the total landmass of the country. It is a Paleozoic sedimentary basin comprising sandstones, shale, limestone, conglomerate, mudstone, siltstone and arkoses. The Voltaian system is divided into three main units: the upper Voltaian (made up of massive sandstones and thin-bedded sandstone); the middle Voltaian (comprising of the Obosum and Oti beds); and the lower Voltaian (Junner and Hirst 1946). Minor et al. (1995) and Dapaah-Siakwan and Gyau-Boakye (2000) worked within the Voltaian but focused largely on the general hydrogeology of the area. However, the application of stable isotopes of oxygen and hydrogen $\left({ }^{18} \mathrm{O}\right)$ and $\left({ }^{2} \mathrm{H}\right)$ in groundwater control mechanisms in the study area is lacking in literature, far from what has been carried out in other parts of the country and elsewhere beyond the boundaries of Ghana. Stable isotopes of oxygen and hydrogen are particularly useful as tracers of hydrological processes in aquifers since their signatures or compositions are not affected by rockwater interactions at the usual low groundwater temperatures (Marfia et al. 2004) and provide insight and support into comprehensive water resources assessment and management.

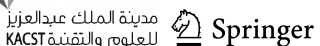

At present, there is no major industry in and around the study area, yet households and municipal wastes are directly discharged into water bodies which may finally end up in the groundwater system. The water supply for human consumption is often directly sourced from groundwater without biochemical treatment and this can cause serious health effects. The Government of Ghana in 2010 launched the Savanna Accelerated Development Authority (SADA) and the construction of the Eastern corridor roads. SADA looks at agricultural development, industrialization, economic and social infrastructure. The study area falls within the jurisdiction of SADA and the Eastern corridor roads also pass through the study area. The construction of roads and implementation of the activities of SADA would open up the area to more business opportunities. The likely emergence of major industries in and around the study area may eventually affect the quality and quantity of water. Hence, there is the need for hydrochemical investigation to determine the quality of the groundwater in the study area, the possible sources of the ions as well as the origin of the groundwater. This will help determine the suitability of groundwater in the study area for drinking water purposes and provide a baseline for future studies of water quality and trends.

\section{The study area}

The Gushegu district lies within longitude $0^{\circ}$ and $45^{\prime} \mathrm{W}$ and latitude $9^{\circ} 30^{\prime}$ and $10^{\circ} 30^{\prime} \mathrm{N}$ and is one of the 18 districts in the Northern region of Ghana. It is much drier due to its proximity to the Sahel and the Sahara. The climate of the study area is tropical and semi-arid. Annual precipitation averages just over $1050 \mathrm{~mm}$, while potential evapotranspiration is about $1770 \mathrm{~mm}$ (Pelig-Ba 2000). There are only about 4-6 months of rainfall during the year, from May to October, the rest, from November to May, is relatively dry and hot. After the rainy period, the northeast trade winds, locally termed the harmattan prevails up to February/March. During the period, the weather becomes very dry and hot in the day but cools to less than $20^{\circ} \mathrm{C}$ in the night. The study area consists predominantly of the Guinea savannah vegetation, characterized by tall grasses interspersed with drought-resistant trees such as Baobab, Shea, Dawadawa and Acacias (Pelig-Ba 2009). Figure 1 is a map of the study area showing the sampling points.

\section{Geology and hydrogeology}

The study area lies entirely within Pendjari or Oti megasequences which represent the middle lithostratigraphic unit, a sub-division of the Paleozoic Voltaian sedimentary formation. It is highly heterogeneous in terms of lithology and dominated by quartzites, shales, mudstones, siltstones, 
MAP OF GUSHIEGU DISTRICT SHOWING SAMPLING LOCATIONS

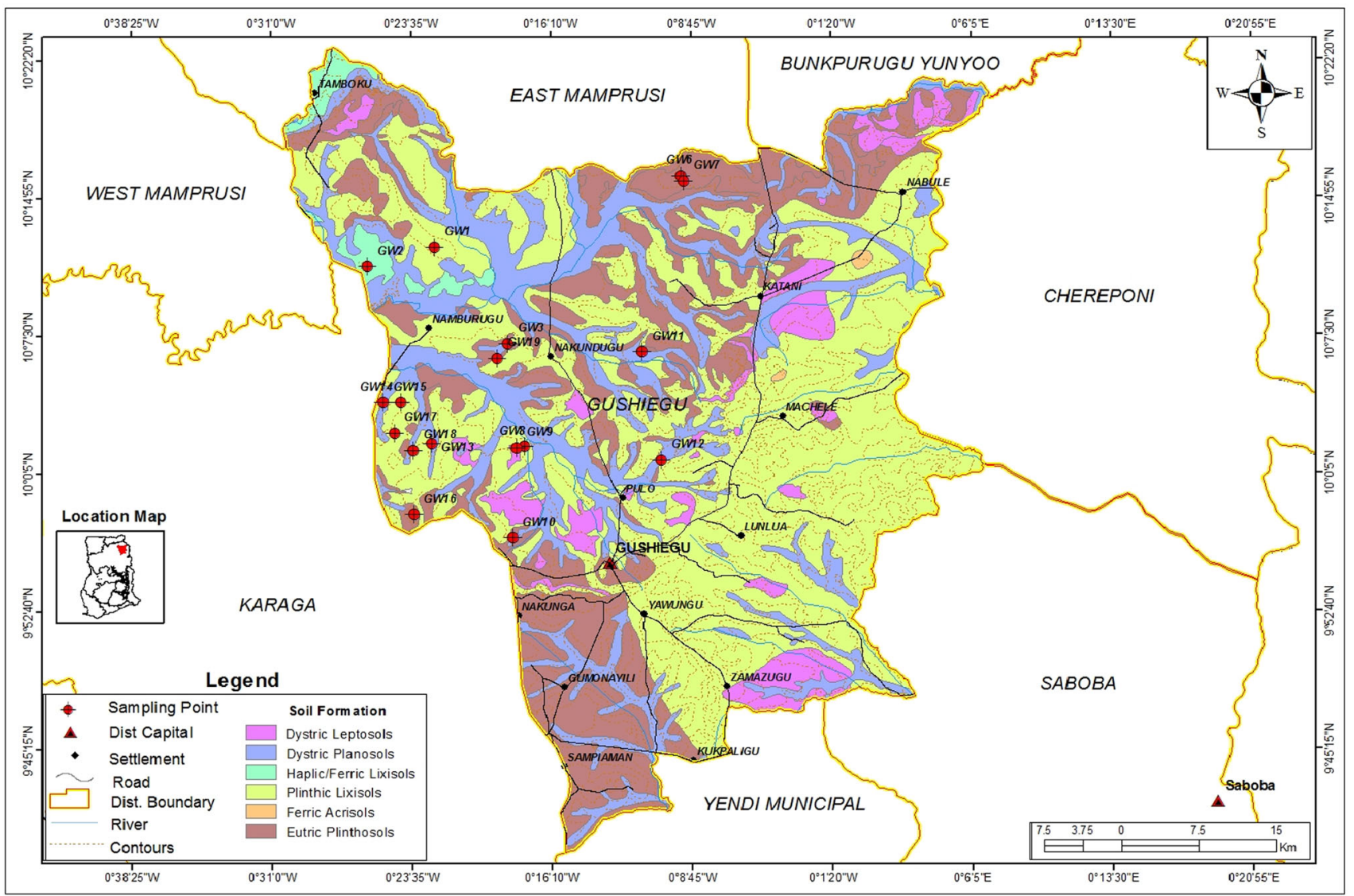

Fig. 1 Location map of the study area showing the sampling points

conglomerates, limestones, tillites, barite-bearing dolomitic carbonates and argillaceous and/or calcareous thin-bedded cherts known as silexites. This group overlies the Panabako formation of the Bombouaka mega-sequence or the Lower Voltaian sub-division (Leprun and Trompette 1969; Affaton et al. 1980; Wright et al. 1985; Hoffman 1999). The northern part of the district is underlain by Bombouaka mega-sequence which consists of fine to coarse-grained and more or less feldspathic sandstones (Bertrand-Sarfati et al. 1990).

The rocks that underlie the study area and Ghana in general are essentially impermeable and have little or no primary porosity. Therefore, groundwater occurrence is associated with the development of secondary porosity as a result of jointing, shearing, fracturing and weathering. This has given rise to two main types of aquifers: the weathered zone aquifers and the fractured zone aquifers. (Ministry of Works and Housing 1998).

The hydraulic conductivities $(K)$ in the study area range from 0.05 to $3.39 \mathrm{~m} \mathrm{day}^{-1}$, while the transmissivity values also ranges from 0.17 to $23.00 \mathrm{~m}^{2}$ day $^{-1}$. Porosity values of the rock samples ranges between 3.9 and $9.7 \%$. Screen lengths for boreholes in the study area ranged from 4.00 to 31.70. According to Dapaah-Siakwan and Gyau-Boakye (2000), the yield of boreholes within the study area ranges between 0.41 and $9 \mathrm{~m}^{3} / \mathrm{h}$, with an average yield of $6.2 \mathrm{~m}^{3} / \mathrm{h}$.

\section{Materials and methods}

A total of nineteen (19) groundwater samples consisting of seventeen (17) boreholes and two (2) hand-dug wells were sampled at various locations following standard protocols as described by Barcelona et al. (1985). Electrical conductivity (EC) and Total Dissolved Solids (TDS) were determined in the field on all samples using the Hach Sension5. $\mathrm{pH}$ and Temperature were also measured in the field using the Hach Sension1. Locations of selected sampling points were determined using the Garmin Vista CP GPS. In sampling from boreholes with hand pumps, purging was done for at least ten (10) min to flush stagnant water retained in the pipes. In the case of hand-dug wells, it was properly checked and confirmed that the well was being used daily. This was to ensure that stale and stagnant

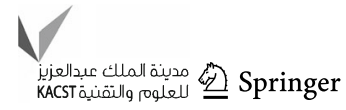


water was not sampled. $330 \mathrm{ml}$ preconditioned polyethylene bottles were used in collecting duplicate water samples. The samples for cations were filtered on site through a $0.45 \mu \mathrm{m}$ filter of acetate cellulose and immediately acidified to a pH less than 2 by addition of Merck TH Ultra-pure nitric acid. The samples for anions were only filtered but not acidified. All water samples were correctly labeled, kept air-tight to prevent evaporation and kept in a refrigerator (except those for isotopic studies) until analyses were carried out. All water analyses were carried out at the chemistry laboratory of the Ghana Atomic Energy Commission (GAEC), Kwabenya. Thin-section preparation was carried out at the Geological Laboratory of the Earth Science Department, University of Ghana.

Major ions such as Sodium $\left(\mathrm{Na}^{+}\right)$and Potassium $\left(\mathrm{K}^{+}\right)$ were analyzed in the laboratory using the flame photometer (Sherwood model 420 with detection limit of 0.001, Eaton et al. 2005). Calcium $\left(\mathrm{Ca}^{2+}\right)$ and Magnesium $\left(\mathrm{Mg}^{2+}\right)$ were analyzed using the AA240FS Fast Sequential Atomic Absorption Spectrometer as prescribed by Eaton et al. (2005), Broekaert (1998), Sperling and Welz (1999) and Sood et al. (2004). The ICS-90 Ion Chromatograph (DIONEX ICS-90) was employed in the analysis of Chloride $\left(\mathrm{Cl}^{-}\right)$, Fluoride $\left(\mathrm{F}^{-}\right)$, Nitrate $\left(\mathrm{NO}_{3}{ }^{-}\right)$, and Sulfate $\left(\mathrm{SO}_{4}{ }^{2-}\right)$. The detection limit and accuracy is $0.0001 \mathrm{mg} / \mathrm{L}$ and 95-105\%, respectively. Phosphate $\left(\mathrm{PO}_{4}{ }^{3-}\right)$ was determined by the ascorbic acid method using the ultraviolet spectrophotometer (UV-1201). The accuracy of the results was confirmed by employing the Charge Balance Error (CBE) as employed by Freeze and Cherry (1979).

\section{Results and discussions}

Table 1 presents a statistical summary of the hydrochemical parameters. Detailed hydrochemical parameters are also presented in Table 2 .

Temperature variation in the study area is presented in Table 1 . The difference in temperature could be attributed to the variation in sampling time and season of the sampling. The lowest and highest temperatures were recorded early in the morning and afternoon, respectively. All the sampling was carried out in six days within the month of October, 2010 just at the onset of the dry season.

The $\mathrm{pH}$ of the water samples analyzed in the study area ranges from weakly acidic to slightly alkaline $(\mathrm{pH}$ of 6.93-7.31), with a standard deviation of 0.09. All the samples fall within the WHO (1996) recommended allowable limits of $6.5-8.5$ for $\mathrm{pH}$ of drinking water.

There is variation in electrical conductivity (EC) of groundwater in the study area ranging from $79.10 \mu \mathrm{S} / \mathrm{cm}$ at Gindigiri to $1663 \mu \mathrm{S} / \mathrm{cm}$ at Makendaya, with a mean of $885.44 \mu \mathrm{S} / \mathrm{cm}$. Of the 19 samples collected, $31.6 \%$ have conductivity values within the WHO (1996) maximum allowable limit of $700 \mu \mathrm{S} / \mathrm{cm}$, while $68.4 \%$ are above the maximum limit. The very high conductivities recorded for some areas may be as a result of increased farming activities which introduce ions and metals from agrochemicals such as fertilizers from farmlands. Furthermore, the higher conductivities in most of the groundwater could also be as a result of higher temperatures (average of $30.37^{\circ} \mathrm{C}$ ); the warmer the water, the higher the conductivity. On the basis of conductivity, groundwater in the study area is generally not potable.

The total dissolved solids (TDS) in the study area vary from 37.70 to $835 \mathrm{mg} / \mathrm{L}$. The lowest and highest TDS values are recorded at Gindigiri and Makendaya, respectively. Makendaya also happens to be the same location where the highest EC value was recorded. The mean TDS is $440.68 \mathrm{mg} / \mathrm{L}$. The low TDS values recorded in the study area could be as a result of the absence of heavy industries in the Gushegu district that release industrial effluents to contaminate the groundwater and increase the TDS. Therefore, the possible sources for TDS in the district may include agricultural run-off and natural sources such as silt, plankton, and the geology. The WHO (1996) recommended maximum allowable limit for TDS in drinking water is $1000 \mathrm{mg} / \mathrm{L}$,

Davis and Dewiest (1966) and Freeze and Cherry (1979) classified groundwater with TDS values within the range $0-1000 \mathrm{mg} / \mathrm{L}$ as fresh, $1000-10,000 \mathrm{mg} / \mathrm{L}$ as brackish, $10,000-100,000 \mathrm{mg} / \mathrm{L}$ as saline water and more than $100,000 \mathrm{mg} / \mathrm{L}$ as brine. Based on this classification, groundwater in the study area is fresh and potable.

Water hardness is a measure of the total concentration of calcium and magnesium ions and to a lesser extent, the salts of other minerals. Hardness in the study area varies from 20 to $232 \mathrm{mg} / \mathrm{L}$, with mean and standard deviation of 105.52 and $62.60 \mathrm{mg} / \mathrm{L}$, respectively. The lowest value of $20 \mathrm{mg} / \mathrm{L}$ was recorded at Nasingbung B1, whilst Makendaya recorded the highest value of $232 \mathrm{mg} / \mathrm{L}$. The WHO (1996) recommended allowable limit for hardness is $500 \mathrm{mg} / \mathrm{L}$. The generally low hardness values recorded could result from the low concentrations of calcium and magnesium in the groundwater. Table 3 represents the classification of groundwater samples based on hardness values.

Out of the 19 samples analyzed, $37 \%$ are soft, $21.05 \%$ are moderately hard, $31.5 \%$ are hard and $10.5 \%$ are very hard. Thus, majority of the samples are within the moderately hard to very hard category and as such cannot be classified as potable.

The $\mathrm{HCO}_{3}{ }^{-}$values range from 18.32 to $793.19 \mathrm{mg} / \mathrm{L}$ with a mean of $430.46 \mathrm{mg} / \mathrm{L}$. The lowest bicarbonate value of $18.32 \mathrm{mg} / \mathrm{L}$ occurs at Gindigiri, whilst the highest value of $793.19 \mathrm{mg} / \mathrm{L}$ occurs at World Vision Guest House. 
Table 1 Statistical summary of hydrochemical parameters

\begin{tabular}{|c|c|c|c|c|c|c|}
\hline Parameter & Unit & Minimum & Maximum & Mean & STD & WHO (1996) \\
\hline Temperature & $\left({ }^{\circ} \mathrm{C}\right)$ & 25.10 & 32.80 & 30.37 & 2.09 & $22-29$ \\
\hline $\mathrm{pH}$ & (pH units) & 6.93 & 7.31 & - & 0.09 & $6.0-9.0$ \\
\hline TDS & $(\mathrm{mg} / \mathrm{L})$ & 37.70 & 835 & 437.52 & 252.95 & 1000 \\
\hline Conductivity & $(\mu \mathrm{S} / \mathrm{cm})$ & 79.10 & 1663 & 885.44 & 454.85 & 700 \\
\hline Hardness & $(\mathrm{mg} / \mathrm{L})$ & 20 & 232 & 105.52 & 62.60 & 500 \\
\hline $\mathrm{Na}^{+}$ & $(\mathrm{mg} / \mathrm{L})$ & 12.94 & 320.48 & 148.49 & 111.30 & 200 \\
\hline $\mathrm{K}^{+}$ & $(\mathrm{mg} / \mathrm{L})$ & 0.46 & 63.83 & 10.09 & 13.94 & 30 \\
\hline $\mathrm{Ca}^{2+}$ & $(\mathrm{mg} / \mathrm{L})$ & 4.36 & 48.88 & 20.58 & 12.66 & 200 \\
\hline $\mathrm{Mg}^{2+}$ & $(\mathrm{mg} / \mathrm{L})$ & 2.47 & 16.99 & 9.19 & 5.11 & 150 \\
\hline $\mathrm{HCO}_{3}^{-}$ & $(\mathrm{mg} / \mathrm{L})$ & 18.32 & 793.19 & 430.46 & 256.59 & 380 \\
\hline $\mathrm{SO}_{4}^{2-}$ & $(\mathrm{mg} / \mathrm{L})$ & 4.75 & 73.96 & 22.87 & 17.78 & 200 \\
\hline $\mathrm{Cl}^{-}$ & $(\mathrm{mg} / \mathrm{L})$ & 4.68 & 121.32 & 21.70 & 26.10 & 250 \\
\hline $\mathrm{NO}_{3}^{-}$ & $(\mathrm{mg} / \mathrm{L})$ & 0.20 & 3.03 & 1.36 & 0.94 & 10 \\
\hline $\mathrm{PO}_{4}{ }^{3-}$ & $(\mathrm{mg} / \mathrm{L})$ & 0.00 & 0.42 & 0.08 & 0.12 & $<0.3$ \\
\hline $\mathrm{F}^{-}$ & $(\mathrm{mg} / \mathrm{L})$ & 0.00 & 1.97 & 0.89 & 0.83 & 1.5 \\
\hline
\end{tabular}

Davis and Dewiest (1966) observed that most bicarbonate ions in groundwater are derived from carbon dioxide in the atmosphere, $\mathrm{CO}_{2}$ in the soil and solution of carbonate rocks. The recommended allowable limit of $\mathrm{HCO}_{3}{ }^{-}$in water by the WHO (1996) is $380 \mathrm{mg} / \mathrm{L}$. The $\mathrm{HCO}_{3}{ }^{-}$concentrations in the study area are generally high, with $53 \%$ exceeding the maximum allowable limit set by the WHO. The source of the $\mathrm{HCO}_{3}{ }^{-}$could be from the solution of carbonate rocks in the study area. On the basis of the WHO (1996) recommended limit for $\mathrm{HCO}_{3}{ }^{-}$, the groundwater is generally not potable.

Sulfate concentration in the study area varies from 4.75 to $73.96 \mathrm{mg} / \mathrm{L}$. The mean concentration is $22.87 \mathrm{mg} / \mathrm{L}$. The lowest value was recorded at Pumo B2 with Mongoli B2 recording the highest value. Sulfate concentrations in natural waters are usually between 2 and $80 \mathrm{mg} / \mathrm{L}$, although they may exceed $1000 \mathrm{mg} / \mathrm{L}$ near industrial discharges (Chapman 1992). High concentrations greater than $200 \mathrm{mg} / \mathrm{L}$ may make water unpleasant to drink. The WHO (1996) recommended guideline for sulfate in groundwater is $200 \mathrm{mg} / \mathrm{L}$. The waters could be said to be potable with respect to sulfate concentration.

Phosphate concentration in the study area varies from below detection limit (BDL) to $0.42 \mathrm{mg} / \mathrm{L}$. The mean concentration is $0.09 \mathrm{mg} / \mathrm{L}$. The phosphate concentrations are generally low, below the WHO (1996) recommended limit of $0.3 \mathrm{mg} / \mathrm{L}$. This makes the water generally potable (Table 4).

Waring (1949) indicated that most nitrate water comes from organic sources or from industrial and agricultural chemicals. Various researchers have also attributed elevated concentrations of nitrate to nearby septic tanks (Hem 2002). Nitrate concentration in the study area ranges from
0.20 to $3.03 \mathrm{mg} / \mathrm{L}$ with a mean of $1.36 \mathrm{mg} / \mathrm{L}$. The nitrate concentration is low; below the WHO (1996) recommended limit of $10 \mathrm{mg} / \mathrm{L}$. Makendaya recorded the lowest nitrate value, whilst the highest value was recorded at Gushegu Secondary School B2. The water from Makendaya is from deep borehole which is relatively well protected from surface polluting activities. The low nitrate values in the groundwater make them generally potable. Although the value is below the permissible limit, it would require constant monitoring to check the nitrate values.

Chloride content in the study area varies from 4.68 to $121.32 \mathrm{mg} / \mathrm{L}$ with a mean of $21.70 \mathrm{mg} / \mathrm{L}$. The highest chloride concentration of $121.0 \mathrm{mg} / \mathrm{L}$ occurs at Makendaya, which still remains below the WHO (1996) recommended limit of $250 \mathrm{mg} / \mathrm{L}$. On the basis of chloride concentrations, the water could be said to be potable.

Sodium ions $\left(\mathrm{Na}^{+}\right)$concentrations varies between 12.94 and $320.48 \mathrm{mg} / \mathrm{L}$ with a mean of $148.49 \mathrm{mg} / \mathrm{L}$. Gindigiri recorded the lowest $\mathrm{Na}^{+}$concentration with Mongoli B1 recording the highest concentration. $57 \%$ of the 19 groundwater samples analyzed fall within the WHO guideline limit of $200 \mathrm{mg} / \mathrm{L}$, whereas $43 \%$ exceeds the WHO guideline limit. Generally, $\mathrm{Na}^{+}$concentrations in the groundwater are below the WHO (1996) maximum permissible limits. However, the $43 \%$ value could pose a health hazard.

Potassium $\left(\mathrm{K}^{+}\right)$concentration in the study area ranges from $0.46 \mathrm{mg} / \mathrm{L}$ at Gushegu Agriculture office to $63.83 \mathrm{mg} / \mathrm{L}$ at Salaa B2. The mean is $10.09 \mathrm{mg} / \mathrm{L}$. The concentrations of potassium in natural waters are usually less than $10 \mathrm{mg} / \mathrm{L}$ (Chapman 1992). The potassium concentration in the study area is generally low except for Salaa B2 which records higher value above the WHO limit of $30 \mathrm{mg} / \mathrm{L}$. This makes the water potable. 


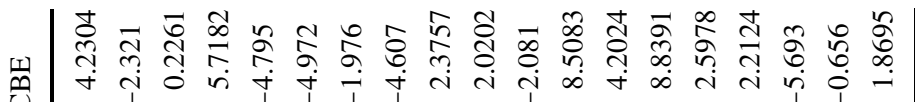

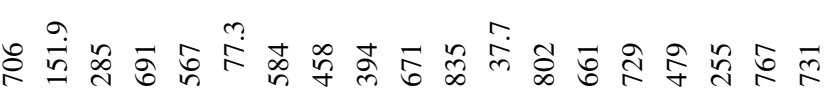
U

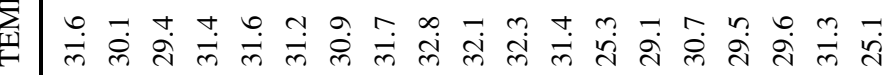

至

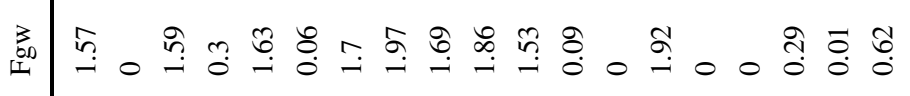

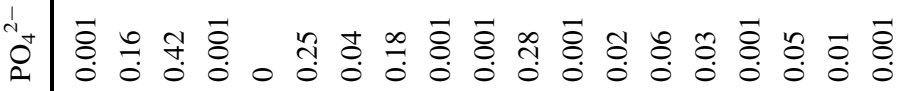

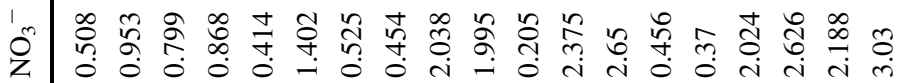

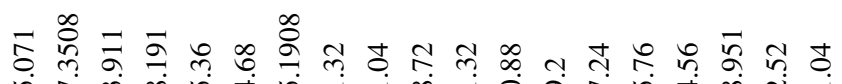

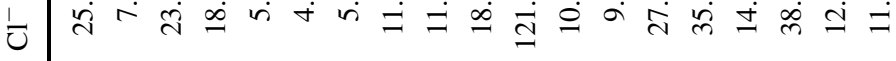

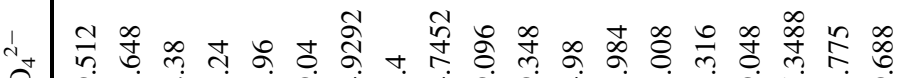

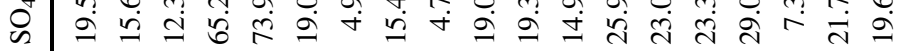
I

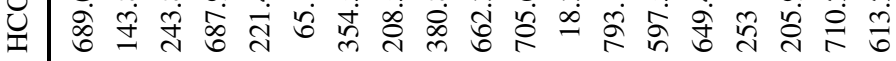

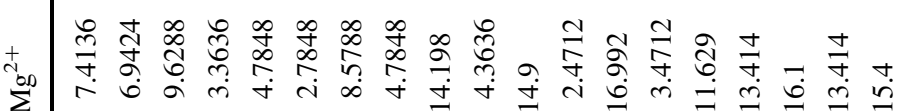

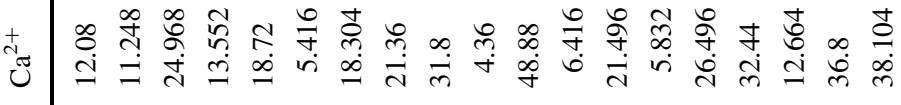

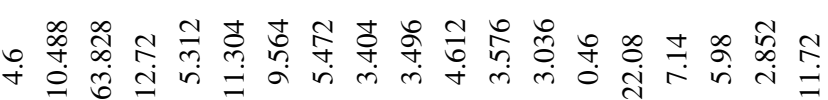

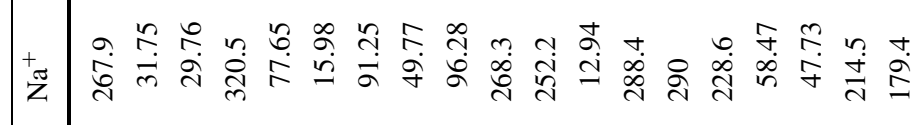
.7

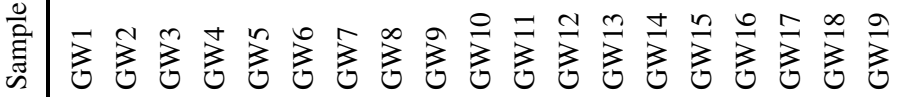
Tr ra ra

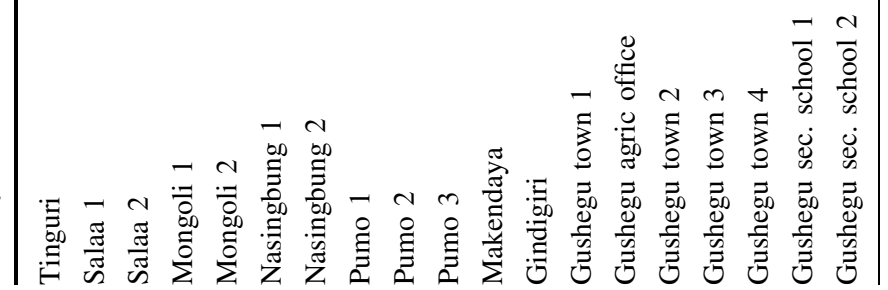


Table 3 Classification of groundwater samples based on hardness values

\begin{tabular}{ll}
\hline Water hardness $\left(\mathrm{CaCO}_{3} \mathrm{mg} / \mathrm{L}\right)$ & Water type \\
\hline $0-60$ & Soft \\
$61-120$ & Moderately hard \\
$121-180$ & Hard \\
$>180$ & Very hard \\
\hline
\end{tabular}

After Brown et al. (1970)

Calcium is largely responsible for water hardness because it can be found in water as $\mathrm{Ca}^{2+}$ ions and may negatively influence toxicity of other compounds. Calcium in the study area ranges from 4.36 to $48.88 \mathrm{mg} / \mathrm{L}$, with a mean of $20.58 \mathrm{mg} / \mathrm{L}$. All the samples from the study area have far less $\mathrm{Ca}^{2+}$ values than the WHO (1996) recommended maximum limit of $200 \mathrm{mg} / \mathrm{L}$. The low $\mathrm{Ca}^{2+}$ and $\mathrm{Mg}^{2+}$ values confirm the low hardness recorded and ultimately makes the water potable.

Magnesium concentration in the study area varies from 2.47 to $16.99 \mathrm{mg} / \mathrm{L}$ with a mean of $9.19 \mathrm{mg} / \mathrm{L}$. The magnesium concentration in the study area is less than the WHO (1996) recommended limit of $150 \mathrm{mg} / \mathrm{L}$, making the water potable.

The Fluoride concentration in the groundwater varies from below detection limit (BDL) to $1.97 \mathrm{mg} / \mathrm{L}$. The mean and standard deviations are 0.89 and $0.83 \mathrm{mg} / \mathrm{L}$, respectively. The highest fluoride concentration of $1.97 \mathrm{mg} / \mathrm{L}$ is recorded at Pumo B1. Out of the 19 water samples analyzed, $52.6 \%$ exceed the WHO (1996) recommended limit of $1.5 \mathrm{mg} / \mathrm{L}$.

\section{Factors influencing observed trends in the hydrochemistry of the area}

Various factors such as the geology of an area, climate and atmospheric depositions control water chemistry. Various works by Ganyaglo et al. (2010), Yidana and Yidana (2010), Kortatsi (2006) and Jalali (2007) have applied the relationship that exists between anions and cations to identify their possible origin in water. The Gibbs (1970) plot is one of the several plots used to determine the possible factors controlling water chemistry in an area. Figure 2 is a Gibbs diagram which shows most of the major ions plotting in the region of rock dominance, with a few plotting in the precipitation dominance zone. This reveals that rock weathering and rainfall are the major possible hydrogeochemical processes regulating the water chemistry of the study area.

$\mathrm{Na}^{+}$correlates positively with $\mathrm{Cl}^{-}$albeit weakly (Table 5). This could suggest that other processes other than dissolution of halite contribute mainly to the $\mathrm{Na}^{+}$ions in groundwater from the study area. The commonest minerals identified in the rocks in the area include plagioclase feldspars, ranging in composition from Albite $\left(\mathrm{NaAlSi}_{3} \mathrm{O}_{8}\right)$ to Anorthite $\left(\mathrm{CaAl}_{2} \mathrm{Si}_{2} \mathrm{SiO}_{8}\right)$, Quartz, Muscovite and Sericite. The $\mathrm{Na}$ ions in the groundwater could be as a result of the weathering of Albite, yielding the metal $\mathrm{Na}^{+}$and silica to solution and forms clay minerals such as illite and montmorillonite. Cation exchange could also contribute to the $\mathrm{Na}^{+}$ions in the groundwater.

The absence of evaporite settings in the soil zone could be a major factor for the generally low chloride values recorded in the study area. The middle Voltaian consists of rocks such as sandstones, siltstones, shales and tuffs which are not rock salts (evaporites). The $\mathrm{Cl}^{-}$could be from precipitation.

The strong correlation between $\mathrm{Ca}^{2+}$ and $\mathrm{Mg}^{2+}$ and to a lesser extent with $\mathrm{HCO}_{3}{ }^{-}$suggests that the majority of $\mathrm{Ca}^{2+}$ and $\mathrm{Mg}^{2+}$ ions in the groundwater in the study area are probably owed to the dissolution of dolomite. Other possible source of $\mathrm{Mg}^{2+}$ ions in the groundwater could be from natural softening by cation exchange where sodiumrich clay displaces $\mathrm{Ca}^{2+}$ and $\mathrm{Mg}^{2+}$ from solution (Ganyaglo et al. 2010).

There is also a weak positive correlation between $\mathrm{Ca}^{2+}$ and $\mathrm{HCO}_{3}{ }^{-}$. This could suggest that although calcite may contribute to the source of ions in the study area, it might be minimal. Weathering of Anorthite and dolomite as well as cation exchange could be possible major contributors to the source of $\mathrm{Ca}^{2+}$ ions in the study area.
Table 4 Summary of petrographical analyses (all the rocks collected were siltstones)

\begin{tabular}{lllllll}
\hline Sample ID & \multicolumn{6}{l}{ Modal composition of major rock mineral $(\%)$} \\
\cline { 2 - 7 } & Sericite & Clay & Iron Oxide & Muscovite & Quartz & Feldspar \\
\hline GSS1 & 2 & 30 & 3 & 5 & 59 & 1 \\
GSS2 & - & 29 & 3 & 4 & 64 & - \\
GSS3 & - & 31 & 1 & 3 & 64 & 1 \\
GSS4 & 4 & 28 & 2 & - & 63 & 3 \\
GSS5 & 2 & 33 & 2 & 3 & 60 & - \\
GSS6 & 2 & 32 & 3 & - & 59 & 4 \\
GSS7 & 1 & 32 & 1 & 2 & 63 & 1 \\
\hline
\end{tabular}




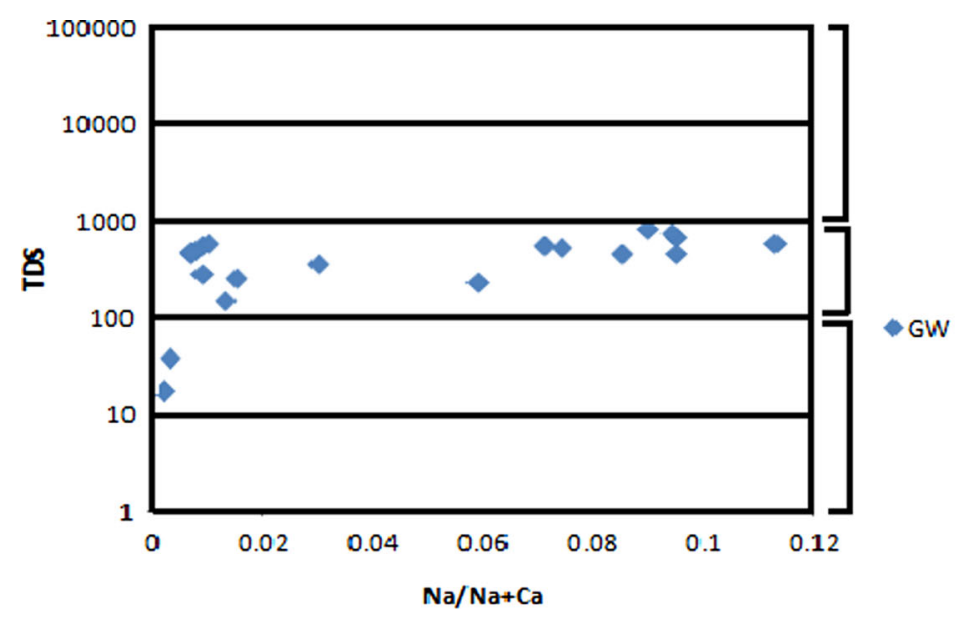

Fig. 2 Gibbs diagram [modified after Gibbs (1970)]

Table 5 Correlation matrix of different water quality parameters at the study area

\begin{tabular}{|c|c|c|c|c|c|c|c|c|c|c|c|c|c|c|}
\hline & $\mathrm{Na}^{+}$ & $\mathrm{K}^{+}$ & $\mathrm{Ca}^{2+}$ & $\mathrm{Mg}^{2+}$ & $\mathrm{HCO}_{3}{ }^{-}$ & $\mathrm{SO}_{4}{ }^{2-}$ & $\mathrm{Cl}^{-}$ & $\mathrm{NO}_{3}^{-}$ & $\mathrm{PO}_{4}{ }^{2-}$ & Fgw & $\mathrm{pH}$ & TEMP & $\mathrm{EC}$ & TDS \\
\hline $\mathrm{Na}^{+}$ & 1 & & & & & & & & & & & & & \\
\hline $\mathrm{K}^{+}$ & -0.259 & 1 & & & & & & & & & & & & \\
\hline $\mathrm{Ca}^{2+}$ & 0.107 & 0.105 & 1 & & & & & & & & & & & \\
\hline $\mathrm{Mg}^{2+}$ & 0.113 & 0.023 & 0.732 & 1 & & & & & & & & & & \\
\hline $\mathrm{HCO}_{3}{ }^{-}$ & 0.953 & -0.172 & 0.336 & 0.351 & 1 & & & & & & & & & \\
\hline $\mathrm{SO}_{4}{ }^{2-}$ & 0.285 & -0.088 & -0.063 & -0.310 & 0.157 & 1 & & & & & & & & \\
\hline $\mathrm{Cl}^{-}$ & 0.320 & 0.003 & 0.469 & 0.323 & 0.339 & -0.100 & 1 & & & & & & & \\
\hline $\mathrm{NO}_{3}{ }^{-}$ & -0.105 & -0.208 & 0.064 & 0.444 & -0.015 & -0.241 & -0.309 & 1 & & & & & & \\
\hline $\mathrm{PO}_{4}{ }^{2-}$ & -0.342 & 0.654 & 0.131 & -0.065 & -0.299 & -0.264 & 0.368 & -0.386 & 1 & & & & & \\
\hline Fgw & 0.107 & 0.042 & -0.018 & -0.243 & 0.088 & -0.080 & 0.175 & -0.483 & 0.185 & 1 & & & & \\
\hline $\mathrm{pH}$ & 0.203 & 0.450 & 0.124 & 0.031 & 0.255 & -0.148 & 0.308 & -0.265 & 0.315 & 0.465 & 1 & & & \\
\hline TEMP & -0.132 & -0.133 & -0.127 & -0.448 & -0.209 & 0.049 & 0.200 & -0.489 & 0.078 & 0.340 & 0.131 & 1 & & \\
\hline EC & 0.735 & -0.204 & 0.503 & 0.386 & 0.806 & 0.310 & 0.414 & -0.269 & -0.212 & 0.271 & 0.264 & -0.099 & 1 & \\
\hline TDS & 0.853 & -0.215 & 0.463 & 0.352 & 0.920 & 0.290 & 0.337 & -0.149 & -0.324 & 0.222 & 0.202 & -0.183 & 0.932 & 1 \\
\hline
\end{tabular}

Bold values indicate significance $\mathrm{P}$ value $(P>0.5)$

The absence of K-feldspars in rocks in the study area could contribute to the low $\mathrm{K}^{+}$levels in the groundwater. Ion exchange in illite may probably be the major process accounting for the $\mathrm{K}^{+}$in the groundwater.

Fluoride in groundwater correlates very weakly and negatively with $\mathrm{Ca}^{2+}(-0.018)$. Fluoride is readily available in water that has low $\mathrm{Ca}^{2+}$ and high $\mathrm{Na}^{+}$concentrations (Larsen and Widdowson, 1971). $\mathrm{F}^{-}$forms strong complexes with other ions, particularly $\mathrm{Ca}^{2+}, \mathrm{Fe}^{3+}, \mathrm{PO}_{4}{ }^{3-}$ and $\mathrm{B}(\mathrm{OH})_{4}^{-}$in solution. The concentration of $\mathrm{F}^{-}$ions in solution is sometimes controlled by the solubility of fluorite; hence, the concentration of $\mathrm{F}^{-}$is often inversely proportional to that of $\mathrm{Ca}^{2+}$. The absence of calcium in solution therefore catalyzes higher concentrations of $\mathrm{F}^{-}$to be stable (Edmunds and Smedley 1996). High fluoride concentrations may therefore be expected in groundwater from calcium-poor aquifers and in areas where fluoridebearing minerals are common. Figure 3 shows that the $\mathrm{F}^{-}$ and $\mathrm{Ca}^{2+}$ do not have any defined correlation or pattern and

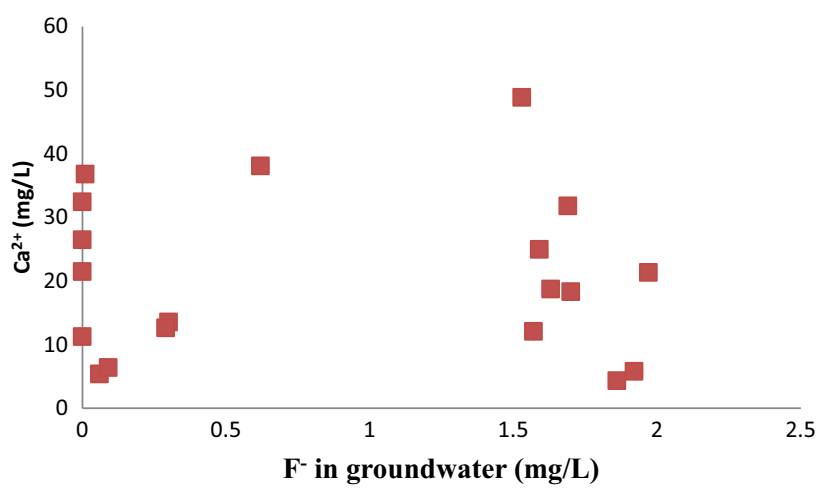

Fig. 3 A plot of $\mathrm{F}^{-}$groundwater against $\mathrm{Ca}^{2+}$ 


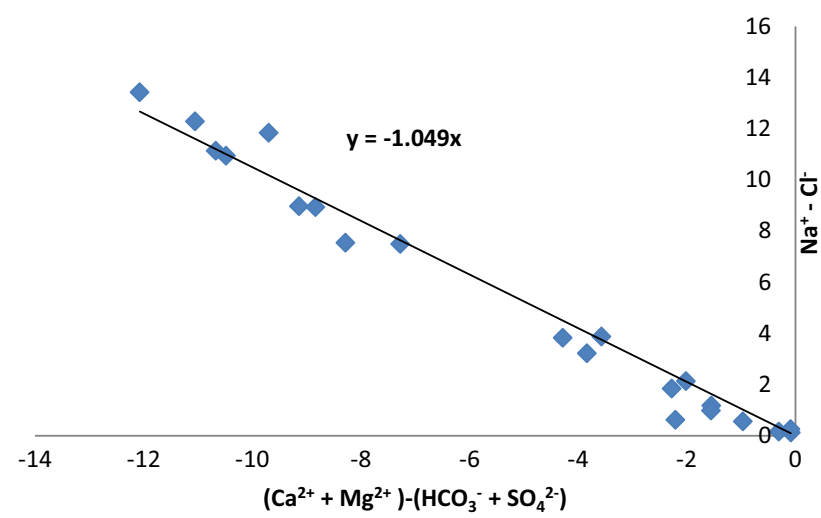

Fig. 4 A plot of $\left[\mathrm{Ca}^{2+}+\mathrm{Mg}^{2+}-\left(\mathrm{HCO}_{3}{ }^{-}+\mathrm{SO}_{4}{ }^{2-}\right]\right.$ against $\left(\mathrm{Na}^{+}-\right.$ $\mathrm{Cl}^{-}$)

as such there could be no concrete conclusion on the possible influence of fluorite in the dissolution of fluoride in the study area. Fluoride is also readily available in areas where fluoride-bearing minerals such as muscovite, hornblende, apatite, and fluorspar are common and these release fluoride into water (Edmunds and Smedley 1996; NAS 1971a). More than $90 \%$ of natural fluoride in soils is bound to clay particles (Lahermo and Backman 2000). Korting (1972) reported that in clay fractions $80-90 \%$ of fluorides are contained in muscovite, illite, and related minerals of the mica group. Fluoride occurs in soil in a variety of minerals and its mobility is determined by the amount of clay minerals present as well as the soil $\mathrm{pH}$ (Wong et al. 2003).

Anthropogenic sources of fluoride may include phosphate fertilizers, mine tailings, and landfilled industrial and municipal wastes (EPA 1980a; NAS 1971a). Absence of mining activities and landfills for industrial and municipal wastes in the communities in the study area makes it less likely that the elevated fluoride concentrations in groundwater would result from contamination from such sources. The possible factors for the elevated fluoride concentrations could be phosphate fertilizers, deposition of fluorides by air and from fluoride-bearing minerals. $95 \%$ of the groundwater was sampled from aquifers located within weakly micaceous mudstones and siltstones. Minerals identified from the rocks in the study area include plagioclase feldspars, iron oxide, muscovite and sericite. Sericite is generally from the alteration of muscovite. The Gibbs plot suggests that rock weathering and precipitation are the major hydrogeochemical processes regulating the water chemistry of the study area. This suggests that the elevated fluoride values may be attributed to the weathering of muscovite and sericite. This is similar to the findings of Anim-Gyampo et al. (2012) and Yidana and Yidana (2010), who attribute the sources of fluoride in the Gushegu district and Keta Basin to the presence of sericite and mineral weathering, respectively. The study area is a sedimentary terrain with much clay contents and this aids in the mobility of the fluoride. Phosphate fertilizers could also contribute to the source of fluoride in groundwater (EPA 1980a) in the study area although it might be minimal. These high $\mathrm{F}^{-}$values have the potential of causing serious health problems such as kidney failure, dental and skeletal fluorosis, reproductive problem and reduction in intelligent quotient of consumers.

The $\mathrm{NO}_{3}{ }^{-}$concentrations in the study area could originate from organic sources such as animal droppings, domestic sewage or aerobic decomposition of organic matter in the soils as well as the application of nitrate fertilizers. The study area is predominantly a farming community where natural fertilizers such as animal droppings are applied in large quantities on farms in addition to moderate amounts of nitrate-bearing artificial fertilizers. These could be eventually leached into the groundwater system. The low concentration of nitrate recorded in groundwater in the study area could be as a result of the absence of heavy industries which otherwise would have released nitrate-containing effluents.

One possible source of the high bicarbonate in groundwater is the soil zone, by dissociation of carbonic acid $\left(\mathrm{H}_{2} \mathrm{CO}_{3}\right)$ generated by the reaction of $\mathrm{CO}_{2}$ with $\mathrm{H}_{2} \mathrm{O} . \mathrm{CO}_{2}$ may be generated by the decay of organic matter in the soil zone (Ganyaglo et al. 2010). The intense farming activities in the study area generate a lot of organic matter. This results in the enrichment of $\mathrm{CO}_{2}$ in the soil zone, which is leached to the groundwater zone as $\mathrm{HCO}_{3}{ }^{-}$. Carbon dioxide in the atmosphere could also contribute to the high $\mathrm{HCO}_{3}{ }^{-}$values in the area.

\section{Cation exchange}

To determine whether cation exchange plays a major role in the hydrochemistry of groundwater from the study area, a scatter plot of $\left[\left(\mathrm{Ca}^{2+}+\mathrm{Mg}^{2+}\right)-\left(\mathrm{HCO}_{3}{ }^{-}+\mathrm{SO}_{4}{ }^{2-}\right)\right]$ in meq/L against $\left(\mathrm{Na}^{+}-\mathrm{Cl}^{-}\right)$in meq/L is carried out (Fig. 4). According to Jankowski et al. (1998), if cation exchange is a significant process in the area, there should be a linear relationship between the two set of parameters, with a slope of -1 . Similarly, the plot displays a linear relationship with a slope of approximately -1 (thus -1.049), indicating that cation exchange is a significant process in the study area.

\section{Water types in the study area}

Groundwater is generally classified into facies depending on the dominant ions present. Figure 5 shows the Piper (1944) trilinear plot of the groundwater in the study area. Two main hydrochemical water types are identified. These 
Fig. 5 Piper (1944) trilinear plot

\section{Piper diagram}

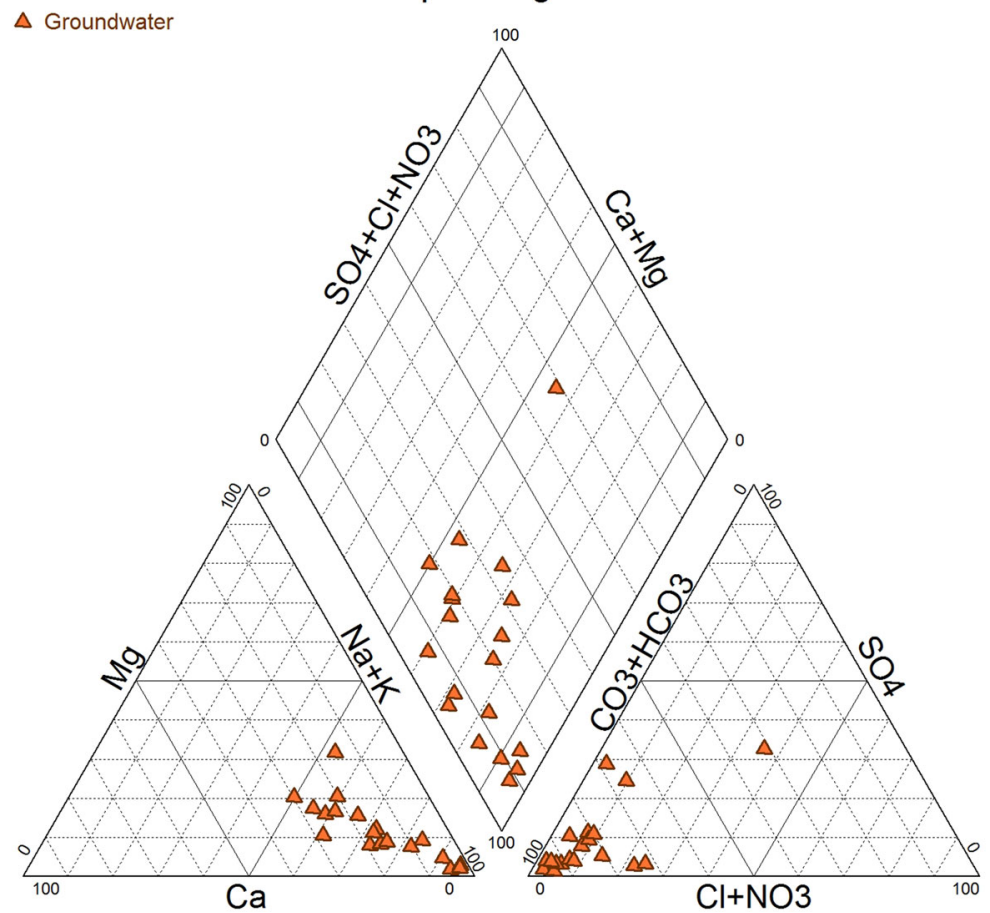

are $\mathrm{Na}-\mathrm{HCO}_{3}$ (water type I) and $\mathrm{Na}-\mathrm{Ca}-\mathrm{Mg}-\mathrm{HCO}_{3}$ (water type II). The major water type identified in the area is the $\mathrm{Na}-\mathrm{HCO}_{3}$ and occupies about $63 \%$ of the water samples in the study area. The origin and evolution of $\mathrm{Na}-\mathrm{HCO} 3$ groundwater have been explained by many authors by combining various hydrogeochemical processes and waterrock interaction reactions. These reactions include (i) the dissolution of $\mathrm{CaCO}_{3}{ }^{-}$in the presence of biogenic $\mathrm{CO}_{2}$ accompanied by $\mathrm{Ca}$ for $\mathrm{Na}$ ion exchange; (ii) a succession of three different reactions: reaction of $\mathrm{Na}$ with kaolinite to form $\mathrm{Na}$-beidellite and $\mathrm{H}+$, followed by dissolution of $\mathrm{CaMg}(\mathrm{CO} 3) 2$ by $\mathrm{H}+$ which releases $\mathrm{CaMg}$ and $\mathrm{HCO} 3$, then exchange of $\mathrm{Ca}$ and $\mathrm{Mg}$ for $\mathrm{Na}$, (iii) the dissolution of dawsonite (NaAlCO3(OH)2 (Maduabuchi et al. 2006). The commonest minerals in the rocks in the study area have been described earlier in this text. The primary source of most sodium in natural water is from the release of soluble products during the weathering of the plagioclase feldspars (Davis and DeWiest 1966; Chapelle and Knobel 1983; Meisler et al. 1984). It may be possible that the plagioclase feldspars (particularly Albite) decomposed to release $\mathrm{Na}^{+}$ in the groundwater. Acheampong and Hess (1998) illustrated the dissolution of plagioclase feldspar to release $\mathrm{Na}^{+}$. The bicarbonate in the groundwater could be from some carbonate mineral dissolution in the aquifer(s) in the area.

The other water type (minor water) is $\mathrm{Na}-\mathrm{Ca}-\mathrm{Mg}-$ $\mathrm{HCO}_{3}$ (water type II) and referred to as the mixed water. In this type of water, no particular cation dominates and the dominant anion is $\mathrm{HCO}_{3}$. Breakdown of plagioclase feldspars, dolomite as well as the $\mathrm{HCO}_{3}$ in the soil zone could be responsible for such mixing of waters.

\section{Isotopes}

The stable isotope content of groundwater in the study area is presented in Table 6 .

Figure 6 is a plot of $\delta^{18} \mathrm{O}$ against $\delta^{2} \mathrm{H}$ to determine the origin of groundwater in the Gushegu district. The Global Meteoric Water Line (GMWL) determined by Craig (1961) and defined by Eq. 1;

$\delta^{2} \mathrm{H}=8 \delta^{18} \mathrm{O}+10$

where $\delta$ is the isotopic enrichment parameter, $\mathrm{O}$ and $\mathrm{H}$ are heavy isotopes of oxygen and hydrogen, respectively, inserted. However, the GMWL is a global line of best fit and as such, may not reflect the local condition. Akiti's (1987) Local Meteoric Water Line (LMWL) defined by Eq. 2 as;

$\delta^{2} \mathrm{H}=7.86 \delta^{18} \mathrm{O}+13.61$

is therefore inserted to serve as a reference for the LMWL in Ghana. This serves as the basis for discussion on the possible origin of groundwaters in the Gushegu District.

The groundwater shows considerable variation in isotopic content. The stable isotope of the groundwater 
Table 6 Stable isotopes content of groundwater in the Gushegu district
Fig. 6 A graph of $\delta^{2} \mathrm{H}$ against $\delta^{18} \mathrm{O}$ of groundwater in the Gushegu District

\begin{tabular}{llll}
\hline Locality & Sample id & $\delta^{18}$ O \%o vs. V-SMOW & $\delta$ D \%o vs. V-SMOW \\
\hline Tinguri & GW1 & -4.62 & -29.83 \\
Salaa B1 & GW2 & -3.77 & -22.63 \\
Salaa HD2 & GW3 & -3.81 & -20.86 \\
Mongoli B1 & GW4 & -5.16 & -28.65 \\
Mongoli B2 & GW5 & -4.85 & -27.98 \\
Nasingbung B1 & GW6 & -4.36 & -23.44 \\
Nasingbung B2 & GW7 & -4.58 & -28.23 \\
Pumo B1 & GW8 & -3.97 & -23.64 \\
Pumo B2 & GW9 & -3.49 & -20.62 \\
Pumo B3 & GW10 & -4.40 & -23.33 \\
Makendaya & GW11 & -3.94 & -20.50 \\
Gindigiri & GW12 & -3.69 & -15.48 \\
World vision guest house & GW13 & -4.07 & -21.23 \\
Gushegu agric office & GW14 & -4.11 & -21.32 \\
World vision office & GW15 & -4.32 & -24.01 \\
Gushegu town & GW16 & -4.47 & -24.29 \\
Gushegu D/A & GW17 & -3.39 & -19.75 \\
Gushegu sec. school B1 & GW18 & -3.95 & -23.40 \\
Gushegu sec. school B2 & GW19 & -4.05 & -21.23 \\
Mean & & -4.10 & -22.64 \\
Minimum & & -5.16 & -29.83 \\
Maximum & & -3.20 & -14.32 \\
\hline & & & \\
\hline
\end{tabular}

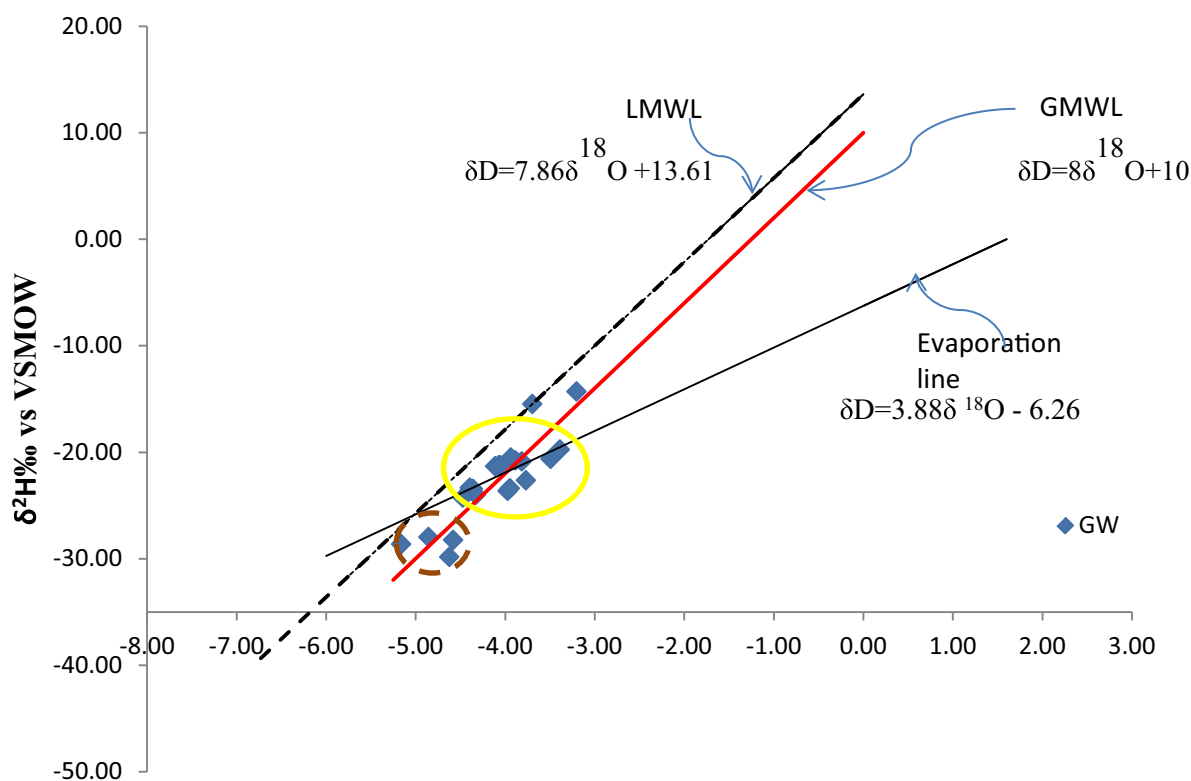

$\delta^{18} \mathrm{O} \%$ vs VSMOW ranges from -5.16 to $-3.39 \%$ and -29.83 to $-15.48 \%$ for $\delta^{18} \mathrm{O}$ and $\delta^{2} \mathrm{H}$, respectively (Table 6). Most of the sample plot on or near the GMWL (circled yellow). Craig (1961), Davis (2002), Domenico and Schwartz (1998) suggest that water with an isotopic composition that falls along the GMWL may probably originate from the atmosphere and is relatively unaffected by isotopic processes. This suggests that the groundwater is likely to be recharged from local precipitation and could be fresh water. The high vegetation canopy could also turn to serve as a shade and thus reduces evaporation rate in the study area. 


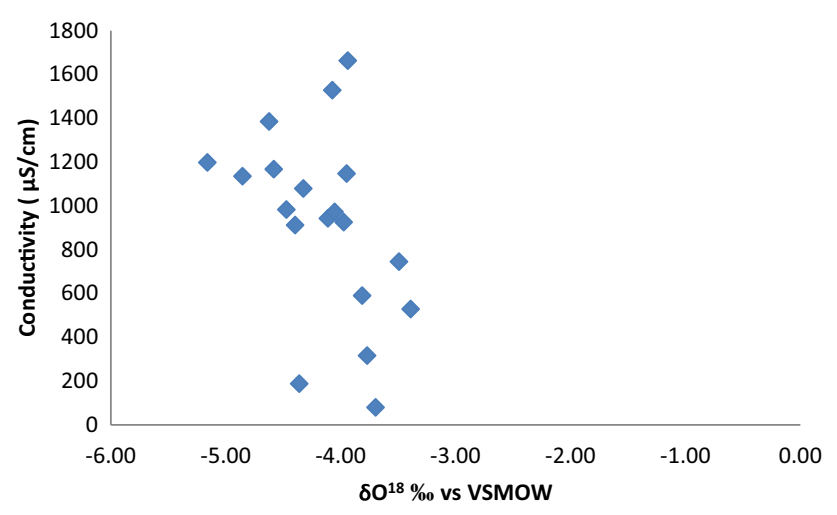

Fig. 7 A graph of conductivity against $\delta^{18} \mathrm{O}$

Tinguri $\left(-4.62 \%\right.$ for $\delta^{18} \mathrm{O}$ and $-29.83 \%$ for $\left.\delta^{2} \mathrm{H}\right)$, Mongoli B1 ( $-5.16 \%$ for ${ }^{18} \mathrm{O}$ and $-28.65 \%$ ), Mongoli B2 $\left(-4.85 \%\right.$ for $\delta^{18} \mathrm{O}$ and $-27.98 \%$ for $\left.\delta^{2} \mathrm{H}\right)$ and Nasingbung B2 (-4.58\%o $\delta^{18} \mathrm{O}$ and $-28.23 \%$ for $\left.\delta^{2} \mathrm{H}\right)$ are relatively more depleted than the other groundwaters, which could suggest that they are relatively old waters. However, a plot of conductivity against ${ }^{18} \mathrm{O}$ (Fig. 7) shows that the ions are mainly as a result of dissolution. This is in agreement with the Gibbs plot which suggests that the sources of ions in the study area are mainly due to precipitation and dissolution.

A few of the groundwater samples, however, show considerable enrichment including the hand-dug wells. This might be an indication that either rainfall might have suffered some level of evaporation before reaching the groundwater table or groundwater might not have been recharged from the local precipitation but from distant sources as was suggested by Pelig-Ba (2009). The handdug wells are open ones and are therefore exposed to direct impact of sunshine and subsequent evaporation.

\section{Conclusions}

Results of groundwater sample analyses in the Gushegu district shows that the $\mathrm{pH}$ is weakly acidic to slightly alkaline. The other physicochemical parameters of groundwater in the Gushegu District suggest that they are generally not potable due to their $\mathrm{F}^{-}, \mathrm{EC}$ and $\mathrm{HCO}_{3}{ }^{-}$ values. 64 and $53 \%$ of the waters recorded levels above the WHO (1996) values of 700 and $380 \mathrm{mg} / \mathrm{L}$ for EC and $\mathrm{HCO}_{3}{ }^{-}$, respectively. Furthermore, the high fluoride contents recorded in about $53 \%$ of the groundwater samples do not make waters from such sources potable. These high values could pose a significant threat to the health of inhabitants of the study area and would require prior treatment of the groundwater before being used for drinking. The study also reveals that the sources of ions in the waters in the study area are mainly mineral weathering and precipitation. Two water types are identified in the Gushegu District. These are $\mathrm{Na}-\mathrm{HCO}_{3}{ }^{-}$and $\mathrm{Na}-\mathrm{Ca}-\mathrm{Mg}-$ $\mathrm{HCO}_{3}{ }^{-}$water types. The former happens to be fresh water and the major water type in the study area. Measurement of environmental isotopes of $\delta \mathrm{D}$ and $\delta^{18} \mathrm{O}$ reveals that most of the groundwater in the Gushegu District is of meteoric origin with some few showing considerable enrichment. However, the absence of rainfall data does not allow for conclusive interpretation of the isotope results.

Open Access This article is distributed under the terms of the Creative Commons Attribution 4.0 International License (http:// creativecommons.org/licenses/by/4.0/), which permits unrestricted use, distribution, and reproduction in any medium, provided you give appropriate credit to the original author(s) and the source, provide a link to the Creative Commons license, and indicate if changes were made.

\section{References}

Acheampong SY, Hess J (1998) Hydrogeological and hydrochemical framework of the shallow groundwater system in the southern Voltaian Sedimentary Basin, Ghana. Hydrogeol J 6:527-537

Affaton P, Sougy J, Trompette R (1980) The tectonic-stratigraphic relationship between the upper Precambrian and lower Paleozoic Volta basin and the pan-African dahomeyide orogenic belt, West Africa. Am J Sci 280:224-248

Akiti TT (1987) Environmental isotope study of groundwater in crystalline rocks of the Accra Plains, Ghana. In: Proceedings of the 4th working meeting, isotopes in nature, Leipzig, September 1986

Anim-Gyampo M, Zango MS, Apori N (2012) The origin of fluoride in groundwaters of the paleozoic sedimentary formations of ghana-a preliminary study in gushiegu district. Res J Environ Earth Sci 4(5):546-552

Apambire WM, Boyle DR, Michel FA (1997) Geochemistry, genesis, and health implications of fluoriferous groundwater in the upper regions of Ghana. Environ Geol 35(1):13-24

Appelo CAJ, Postma D (1993) Geochemistry, Groundwater and Pollution. A.A Balkema, Rotterdam

Back W (1966) Hydrochemical facies and ground-water flow patterns in northern part of Atlantic Coastal Plain: U.S. Geological Survey Professional Paper 498-A

Barcelona M, Gibb JB, Helfrich JA, Garske EE (1985) Practical Guide for Groundwater Sampling, Illinois State Water Survey ISWS, Contract Report 374

Bertrand-Sarfati J, Moussine-Pouchkine A, Affaton P, Trompette R, Bellion Y (1990) Cover sequences of the West African craton. In: Dallmeyer RD, Lecorche JP (eds) The West African Orogens and Circum-Atlantic Correlatives. Springer, Berlin, pp 65-84

Broekaert JAC (1998) Analytical atomic spectrometry with flames and plasmas, 3rd edn

Brown E, Skougstad MW, Fishman MJ (1970) Methods for collection and analysis of water samples for dissolved minerals and gases, chap. A1 in Book 5 of Techniques of Water Resources Investigation of the U.S. Geological Survey.U.S. Government Printing Office, Washington, D.C., p 160

Chapelle FH, Knobel LL (1983) Aqueous geochemistry and the exchangeable cation composition of glauconites in the Aquio aquifer, Maryland. Groundwater 21(3):343-352 
Chapman D (1992) Water quality assessments. A guide to the use of Biota, sediments and water in the environmental monitoring, 2nd edn. E \& FN SPON, An Imprint of Chapman \& Hall, London, pp 413-510

Craig H (1961) Isotopic variation in meteoric water. Science 133:1702-1703

Dapaah-Siakwan S, Gyau-Boakye P (2000) Hydrogeologic framework and borehole yields in Ghana. Hydrogeol J 8(4):405-416

Davis J (2002) Statistics and data analysis in geology. Wiley, New York

Davis SN, DeWiest RGM (1966) Hydrogeology New York. Willey, London, p 463

Domenico P, Schwartz F (1998) Physical and chemical hydrogeology, 2nd edn. Wiley, New York

Drever JI (1988) The geochemistry of natural waters, 2nd edn. Prentice Hall, New Jersey

Eaton AD, Clesceri LS, Greengerg AE (2005) (eds). Standard methods for the examination of water and wastewater, American Public Health Association, 1015 Fifteenth Street, Washington

Edmunds WM, Smedley PL (1996) Groundwater geochemistry and health: an overview. In: Appleton, Fuge, McCall (eds) Environmental geochemistry and health. Geological Society Special Publication, vol 113, pp 91-105

EPA (1980a). Review of the environmental effects of pollution: IX. Fluoride. Cincinnati, OH: Health Effects Research Laboratory, Office of Research and Development, U.S. Environmental Protection Agency. EPA-600/1-78-050

Foster SSD, Chilton PJ, Moench MK, Cardy F, Schiffler M (2000) Groundwater in rural development: Facing the challenges of resource sustainability. World Bank Technical Paper No. 463. World Bank, Washington D.C

Freeze RA, Cherry JA (1979) Groundwater. Prentice-Hall, Englewood Cliffs

Ganyaglo SY, Banoeng-Yakubo B, Osae S, Dampare SB, Fianko JR (2010) Water quality assessment of groundwater in some rock types in parts of the eastern region of Ghana. DOI, Environ Earth Sci. doi:10.1007/s12665-010-0594-3

Gibbs RJ (1970) Mechanisms controlling world water chemistry. Science 17:1088-1090

Hem JD (1991) Study and interpretation of the chemical characteristics of natural waters, Book 2254, 3rd edn. Scientific Publishers, Jodhpur

Hem JD (2002) Study and interpretation of the chemical characteristics of natural water. US Geochemical Survey Water Supply, Paper 2254

Hoffman PF (1999) The break-up of Rodinia, birth of Gondwana, true polar wandering and the snowball Earth. J Afr Sci 28:17-33

Jalali M (2007) Hydrochemical identification of groundwater resources and their changes under the impacts of human activity in the Chah Basin in Western Iran. Environ Mon Assess 130:347-364

Jankowski J, Acworth RI, Shekarforoush S (1998). Reverse ion exchange in a deeply weathered porphyritic dacite fractured aquifer system, Yass, New South Wales, Australia. In: Arehart GB, Hulston JR (eds) Proceedings of the 9th international symposium. Water-rock interaction, Taupo, New Zealand, 30 March-3, April 1998. Balkema, Rotterdam, pp 243-246

Junner RR, Hirst T (1946) The Geology and Hydrogeology of the Voltaian Basin. Gold Coast Geological Survey Memoir 8, Gold Coast Geological Survey, Accra, Ghana

Kortatsi BK (2006) Hydrochemical characterisation of groundwater in the Accra plains of Ghana. Environ Geol 50:293-311

Korting, S (1972). Fluoride 9B-9O Hand Book of Geochemistry, II/1. Springler-Verlag

Lahermo P, Backman B (2000) The occurrence and geochemistry of fluorides with special reference to natural waters in Finland. Geological Survey of Finland, Espoo 2000, p 40
Larsen S, Widdowson AE (1971) Soil fluorine. J Soil Sci 22:210-222

Leprun JC, Trompette R (1969) Subdivision du Voltaien du massif de Gobnangou (République de Haute-Volta) en deux séries discordantes séparées par une tillite d’âge éocambrien probable. Comptes Rendus Académie des Sciences Paris 269:2187-2190

Maduabuchi C, Faye S, Maloszewski P (2006) Isotope evidence of palaeorecharge and palaeoclimate in the deep confined aquifers of the Chad Basin, NE Nigeria. Sci Total Environ 370:467-479

Marfia AM, Krishnamurthy RV, Atekwana EA, Panton WF (2004) Isotopic and geochemical evolution of groundwater and surface waters in a karst dominated geological setting: a case study from Belize, Central America. Appl Geochem 19:937-946

Meisler H, Leahy PP, Knobel LL (1984) Effect of eustatic sea-level changes on saltwater fresh water relations in the northern Atlantic Coastal Plain: US Geological Survey Water-Paper 2255, p 28

Minor T, Russel C, Chesley M, Englin J, Sander P, Carter RK, Acheampong SY, McKay A (1995) Application of geographic information systems technology to water well citing in Ghana, West Africa: feasibility study. Desert River Research Institute, Publication No. 44033, p 168

Ministry of Works and Housing (1998) "Water Resources Management Study, Information 'Building Block' Study. Part II, Volta Basin System, Groundwater Resources."Ministry of Works and Housing, Accra

NAS (1971a).U.S. National Academy of Sciences."Fluorides".Committee on Biologic Effects of Atmospheric Pollutants. Div. Med. Sci., National Research Council. Washington, D.C., p 295

Olayinka AI (1999) Electromagnetic profiling and resistivity soundings in groundwater investigation near Egbeda, Kabba, Kwara State. J Min Geol 27(2):243-250

Pelig-Ba KB (2000) Hydrogeochemistry of the Birrimian Metasediments and the Voltaian Sediments of the Northern Region of Ghana. PhD Thesis. University of Reading, Reading

Pelig-Ba KB (2009) Analysis of stable isotope contents of surface and underground water in two main geological formations in the Northern region of Ghana. West Afr J Appl Ecol, vol 15

Piper AM (1944) A graphic procedure in the geochemical interpretation of water analyses. Am Geophys Union Trans 25:914-992

Raji BA, Alagbe SA (1997) Hydrochemical facies in parts of the Nigerian Basement Complex. Environ Geol 29:46-49

Sood DD, Reddy AVR, Ramamoorthy N (2004) Fundamentals of Radiochemistry, 2nd edn. Perfect Prints, Jyoti Industrial Estate, India, pp 272-279

Sperling MB, Welz B (1999) Atomic absorption spectrometry. WileyVCH, Weinheim. ISBN 3-527-28571-7

UNESCAP (2000) State of the Environment in Asia and the Pacific, 2000. United Nations, New York

Waring FG (1949) Significance of nitrate in water supplies. Am Water Works Assoc J 41:147

WHO (1996).Guidelines for Drinking Water, vol 2. Recommendations, World Health Organisation, Geneva

Wong MH, Fung KF, Carr HP (2003) Aluminium and fluoride contents of tea, with emphasis on brick tea and their health implications. Toxicol Lett 137:111-120

Wright JL, Hastings DA, Jones WB, Williams HR (1985) Geology and mineral resources of west Africa. 1st edn. George Allen and Unwin (Publishers) Ltd., London, pp 187

Yidana SM, Yidana A (2010) Assessing water quality using water quality index and multivariate analysis. Environ Earth Sci 59:1461-1473

Yidana SM, Ophori D, Banoeng-Yakubo B (2008) Hydrogeological and hydrochemical characterization of the voltaian basin: the Afram plains area. Ghana Environ Geol 55:1213-1223 